\title{
Massive transfusion in the trauma patient: Continuing Professional Development
}

\author{
Megan A. Hayter, MD • Katerina Pavenski, MD • \\ James Baker, MD
}

Received: 22 June 2012/ Accepted: 18 September 2012/Published online: 18 October 2012

(c) Canadian Anesthesiologists' Society 2012

\begin{abstract}
Purpose Massive transfusion has recently been given a dynamic definition, namely, the replacement of more than four red cell concentrates within an hour. The purpose of this continuing professional development module is to review the pathophysiology of hemorrhagic shock in the trauma patient and the current management strategies of the massively bleeding trauma patient.

Principal findings The massively bleeding trauma patient requires concurrent hemorrhage control and blood replacement therapy. Although there are many complications of massive transfusions, such as acid-base disturbances, electrolyte abnormalities, and hypothermia, perhaps the most difficult aspect to manage is acute trauma coagulopathy. Historically, coagulopathy was attributed to dilution of coagulation factors; however, recent accumulated evidence indicates that it is a multifactorial process associated with hypoperfusion, factor consumption, and hyperfibrinolysis. In an attempt to minimize acute trauma coagulopathy, massive transfusion protocols with equal ratios of red cell concentrates, frozen plasma, and platelets have been proposed. This type of hemostatic resuscitation, with near equal ratios of blood and blood products, has improved survival, but it is not without risk. In addition to the rapid and effective restoration of blood volume, the specific goal of transfusion management should be to
\end{abstract}

M. A. Hayter, MD · J. Baker, MD ( $\varangle)$

Department of Anesthesiology, St. Michael's Hospital,

University of Toronto, Toronto, ON, Canada

e-mail: bakerja@smh.ca

K. Pavenski, MD

Department of Transfusion Medicine, St. Michael's Hospital,

University of Toronto, Toronto, ON, Canada maintain the patient's oxygen carrying capacity, hemostasis, and biochemistry.

Conclusion The current literature does not permit firm conclusions to be drawn regarding optimal transfusion ratios. It remains appropriate, however, to devise a massive transfusion protocol at the institutional level that provides treating physicians with rapid delivery of a reasonable initial ratio of products. This would permit patientcentred management with an emphasis on surgical control of bleeding, maintenance of normothermia, avoidance of electrolyte abnormalities, acid-base balance, and the timely delivery of blood products.

Objectives After reading this module, the reader should be able to:

1. Enumerate the complications associated with massive transfusion in the trauma context;

2. Understand how the coagulopathy present in the trauma patient differs from that seen in the elective setting;

3. Identify the modifications suggested by the recent literature for the management of massive transfusion in the trauma setting;

4. Appreciate the evidence for the institution of massive transfusion protocols.

\section{Summary review}

Uncontrolled hemorrhage requiring massive transfusion is most commonly seen during trauma surgery and remains a leading cause of death. ${ }^{1-3}$ In trauma victims, the extent of tissue damage may be unpredictable, and the interval between hemorrhage and treatment can vary widely. ${ }^{1}$ 
Coagulopathy is frequent in this setting due to hypothermia, acidosis, tissue injury, hypoperfusion, dilution, and consumption of clotting factors and platelets. ${ }^{1,4}$ Hemorrhagic shock is a pathophysiological state in which the circulatory system is unable to meet its oxygen requirements and perfuse the tissues adequately. ${ }^{5}$ The main principles in managing hemorrhagic shock include control of bleeding, replacement of circulating volume, and restoration of oxygen carrying capacity. Then again, there remains a need for restricting transfusion in light of the potential complications associated with transfusion of blood and blood products.

A study conducted in Ontario revealed that trauma patients receive $13.4 \%$ of all blood products transfused, and $3 \%$ of these victims require a massive transfusion. ${ }^{5}$ Approximately $50 \%$ of trauma patients requiring a massive transfusion are coagulopathic; therefore, there is a need to provide clinicians with guidelines to manage these complex patients. Massive transfusion has been defined loosely as the replacement of one blood volume in a $24-\mathrm{hr}$ period. ${ }^{6}$ Although, a more dynamic definition of massive transfusion includes the transfusion of at least four red cell concentrates within one hour and an ongoing need for blood replacement in the foreseeable future. ${ }^{6}$ The management of a massively bleeding patient is complex and is aimed at concurrent hemorrhage control and blood volume replacement. ${ }^{1}$ Moreover, in order to improve survival, management should be aimed at preventing the multifactorial complications associated with massive transfusion. In this review, we outline the complications associated with massive transfusion and the mechanisms of transfusioninduced coagulopathy. Specifically, we discuss how trauma-induced coagulopathy differs from coagulopathy seen in the elective setting. Lastly, we present recent advances in massive transfusion management, including point-of-care testing, transfusion ratios, and the institution of massive transfusion protocols.

\section{Complications related to massive transfusion}

There are several well-established acute and delayed complications of massive transfusion, including electrolyte abnormalities, acidosis, hypothermia, infection, transfusion-associated acute lung injury, transfusion-associated circulatory overload, and coagulopathy. ${ }^{7}$

Electrolyte abnormalities and acid-base disturbances (Table 1)

Various electrolyte abnormalities and acid-base disturbances can be present in patients requiring massive transfusion. Hyperkalemia was documented in $38.5 \%$ of transfused non-crush injury trauma victims compared with $2.8 \%$ of non-transfused patients. ${ }^{7}$ Potassium concentration in red blood cell (RBC) concentrates increases with storage

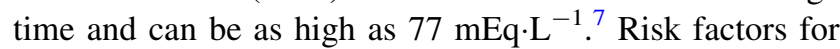
transfusion-associated hyperkalemia include the absolute number of RBC units transfused, underlying renal insufficiency, rate of blood transfusion, and severe tissue injury. ${ }^{7}$ Hypokalemia can also be evident post-transfusion and appears to be related to the RBC membrane ATPase pump; the release of aldosterone, antidiuretic hormone and catecholamines; and citrate administration. Each RBC unit contains $3 \mathrm{~g}$ of citrate, the anticoagulant present in stored blood, and $3 \mathrm{~g}$ of citrate is the approximate amount that the healthy adult liver can metabolize every five minutes. Consequently, transfusion rates greater than one RBC unit every five minutes or impaired liver function may result in a metabolic alkalosis and hypocalcemia secondary to citrate toxicity. ${ }^{7}$ Also, hypomagnesemia secondary to the infusion of magnesium-poor fluids and citrate binding of magnesium may result in a prolongation of the QT interval during massive transfusion.

Patients requiring a massive transfusion may also develop acid-base disturbances secondary to tissue hypoperfusion and normal saline administration. ${ }^{4}$ The initial appearance of a metabolic acidosis may be an indicator of poor tissue perfusion, which generally responds to aggressive resuscitative measures. Importantly, acidosis exacerbates the coagulopathy because platelets change their shape at a $\mathrm{pH}<7.4$ and thrombin generation is inhibited at a $\mathrm{pH}<7.1 .^{4}$ Lastly, acidosis accelerates fibrinolysis, which exacerbates the coagulopathy. ${ }^{4}$

\section{Hypothermia (Table 1)}

General anesthesia has been shown to impair normal thermoregulatory control. ${ }^{8}$ Hypothermia during general anesthesia follows a characteristic pattern. There is a large initial decrease due to redistribution, followed by a slower decline secondary to heat loss exceeding metabolic heat production. ${ }^{8}$ In the elective surgical setting, hypothermia can usually be prevented with the infusion of warmed fluids because the core body temperature is normal at the outset. In contrast, the trauma patient is at greater risk of hypothermia for several reasons, including exposure, initial infusion of unwarmed fluids, opening of body cavities, and altered thermoregulatory control. Hypothermia has many adverse consequences, such as decreased citrate metabolism, decreased drug clearance, decreased synthesis of acute phase reactants, and decreased production of clotting factors, all of which exacerbate coagulopathy. ${ }^{7}$ Moreover, hypothermia causes a reversible platelet dysfunction, significantly alters the coagulation cascade, and enhances fibrinolysis. ${ }^{1,4,7}$ There is a $10 \%$ reduction in coagulation 
Table 1 The adverse effects of hypothermia, citrate toxicity, and hypocalcemia with regard to massive transfusion and initial management principles

\begin{tabular}{|c|c|c|}
\hline & Adverse Effects & Management Principles \\
\hline Hypothermia & $\begin{array}{l}\text { Decreased citrate metabolism } \\
\text { Decreased hepatic metabolism } \\
\text { Decreased drug clearance } \\
\text { Decreased synthesis of acute phase } \\
\text { reactants } \\
\text { Decreased production of clotting factors }\end{array}$ & $\begin{array}{l}\text { Elevation of room temperature } \\
\text { Surface warming of the patient with } \\
\text { heating lamps \& blankets Infusion } \\
\text { of warmed fluids } \\
\text { Use of heated \& humidified gases }\end{array}$ \\
\hline Citrate Toxicity & $\begin{array}{l}\text { Tetany } \\
\text { Prolonged QT } \\
\text { Decreased myocardial contractility } \\
\text { Hypotension } \\
\text { Elevated end-diastolic pressures } \\
\text { Hypocalcemia }\end{array}$ & $\begin{array}{l}\text { Monitoring and maintenance of serum } \\
\text { calcium concentrations }\end{array}$ \\
\hline Hypocalcemia & $\begin{array}{l}\text { Prolonged QT } \\
\text { Myocardial depression } \\
\text { Decreased peripheral vascular resistance } \\
\text { Tremors } \\
\text { Pulseless electrical activity \& ventricular } \\
\quad \text { fibrillation }\end{array}$ & $\begin{array}{l}\text { Intravenous calcium administration } \\
\text { (e.g., } 10 \% \text { calcium gluconate } \\
\text { contains } 9 \text { mg elemental calcium } \\
\text { vs. calcium chloride which contains } \\
27 \text { mg elemental calcium) }\end{array}$ \\
\hline Hypomagnesemia & Prolonged QT & $\begin{array}{l}\text { Intravenous magnesium } \\
\text { administration }\end{array}$ \\
\hline Metabolic Acidosis & $\begin{array}{l}\text { Coagulopathy } \\
\text { Hemodynamic instability } \\
\text { Renal dysfunction }\end{array}$ & $\begin{array}{l}\text { Aggressive fluid resuscitation } \\
\text { Restoration of tissue perfusion } \\
\text { Monitor base excess } \\
\text { Temporize with } \mathrm{NaHCO}_{3}\end{array}$ \\
\hline Hyperkalemia & $\begin{array}{l}\text { Peaked } \mathrm{T} \text { waves } \\
\text { Ventricular fibrillation }\end{array}$ & $\begin{array}{l}\text { Calcium gluconate } \\
i v \mathrm{D} 50 \mathrm{~W} \\
10 \mathrm{U} i v \text { insulin }\end{array}$ \\
\hline Hypokalemia & & $\begin{array}{l}\text { Correct metabolic alkalosis } \\
\text { Limit infusion of K-poor containing } \\
\text { fluids }\end{array}$ \\
\hline Coagulopathy & Impaired hemostasis & $\begin{array}{l}\text { Damage control surgery } \\
\text { Minimize factor depletion and } \\
\text { fibrinolysis } \\
\text { Correct acidosis, hypocalcemia } \\
\text { Maintain normothermia }\end{array}$ \\
\hline
\end{tabular}

factor activity for every $1^{\circ} \mathrm{C}$ decrease in temperature. ${ }^{7}$ Importantly, the effect that hypothermia has on the coagulation cascade can be underestimated as coagulation assays are performed at $37^{\circ} \mathrm{C}$. Steps to be taken to prevent hypothermia in both elective and trauma settings include infusing warmed fluids, elevating room temperature, and warming the patient with forced-air blankets.

Transfusion-related acute lung injury

Transfusion-related acute lung injury (TRALI) is defined as acute-onset hypoxemia with bilateral lung infiltrates on chest radiographs in the absence of any evidence of circulatory overload. The complication occurs within six hours of receiving a transfusion, and it is not related to other causes of acute lung injury or acute respiratory distress syndrome. ${ }^{7}$ Transfusion-related acute lung injury is a leading cause of major morbidity and mortality related to transfusion. ${ }^{9,10}$ There are two distinct mechanisms postulated to be responsible for the development of TRALI: the passive transfer of antileukocyte antibodies from alloimmunized donors and biological response modifiers that have accumulated during the storage of blood products. ${ }^{9}$ Although blood product transfusion is an independent risk factor for the development of TRALI, the risk of developing TRALI varies with type of blood product. For example, plasma transfusion is associated with a 1:2000 risk of developing TRALI, which is a greater risk than that of RBC transfusion, which carries a 1:5000 risk. ${ }^{7,9}$ Supporting the antileukocyte antibodies mechanism, donor sex 
does seem to play a role in contributing to TRALI. Approximately $10-20 \%$ of female donors with a history of pregnancy contain antileukocyte antibodies. ${ }^{11}$ Measures to reduce TRALI, such as diverting female plasma for fractionation and suspending platelet concentrates in male plasma, are currently in use in Canada, the United Kingdom, and the United States.

\section{Trauma-induced coagulopathy}

The coagulopathy associated with massive transfusion is a multifactorial and multicellular process. ${ }^{6}$ Undoubtedly, dilution of clotting factors occurs when there is coagulopathy associated with massive transfusion ${ }^{12}$; however, this process is not solely dilutional in nature, and consumption of clotting factors and hyperfibrinolysis also play a significant role. ${ }^{7,13}$ Traditional models that explain coagulation defects as though they were expressly acquired through external trauma and resuscitation-related insults, such as hemodilution, hypothermia, acidosis, and factor depletion, are insufficient. ${ }^{14}$ Rather, a subset of acute trauma patients show a very early presentation of coagulopathy that appears quite distinct in its mechanism from traditional concepts of acquired coagulation defects. Although trauma-associated coagulopathy has various names, such as acute traumatic coagulopathy, early traumainduced coagulopathy, endogenous acute coagulopathy, and acute coagulopathy of trauma shock, we refer to it as acute traumatic coagulopathy for the remainder of this review. The observable coagulation defect in acute traumatic coagulopathy presents early and is increasingly recognized to result from the activation of endogenous protease cascades in the presence of shock. These cascades create a hypocoagulable state that operates independently from the predictable effects of factor depletion and dilution and protease dysfunction secondary to acidosis and hypothermia.

Acknowledging that acute traumatic coagulopathy is unlikely to have a singular underlying mechanistic explanation, Brohi et al. ${ }^{15}$ developed a plausible explanation for the coagulopathy that may occur in approximately $25 \%$ of cases. $^{16}$ This coagulopathy is not attributable to the development of acidosis, factor depletion, or hypothermia. Central to this mechanism is the observation that the coagulopathy rarely develops without the inciting effects of shock and tissue hypoperfusion. ${ }^{15}$ Tissue hypoperfusion results in endothelial expression of thrombomodulin, which complexes with thrombin that is appropriately generated by the inciting injury; the resulting aggregate activates protein $\mathrm{C}$ to form activated protein $\mathrm{C}$. In this way, two distinct mechanisms of hypocoagulability are identified: firstly, activated protein $\mathrm{C}$ inactivates factor $\mathrm{Va}$ and factor VIIIa, and secondly, thrombin is diverted from its natural role in fibrin formation because it complexes with thrombomodulin instead (Figs. 1 and 2).

In addition, shock-induced activated protein $\mathrm{C}$ formation results in the consumption of plasminogen activator inhibitor. The latter normally serves to downregulate tissue plasminogen activator (tPA) in its role (via plasmin formation from plasminogen) in promoting fibrin clot degradation. Activated protein $\mathrm{C}$ thus serves to unbridle the tendency of traumatized endothelium to initiate fibrinolysis (via tPA expression); therefore, fibrinolysis is also understood to be an important component in the overall mechanism of traumatic coagulopathy.

\section{Management of massive transfusion in the trauma setting}

Management of the hemorrhaging trauma patient includes hemorrhage control and concurrent volume replacement. Historically, the hemorrhaging patient was managed chiefly with isotonic crystalloid and plasma-poor RBC concentrates. In a large retrospective review, trauma patients requiring transfusion of $>50$ units of RBCs within the first $24 \mathrm{hr}$ of admission had a mortality rate of $57 \% .^{17}$ Even so, this traditional method of managing massive transfusion fails to address that $25 \%$ of trauma victims develop an early and profound coagulopathy that may worsen with RBC transfusion due to a dilutional coagulopathy. ${ }^{18}$ Therefore, in addition to the rapid and effective restoration of blood volume, the specific goal of transfusion management should be to maintain the patient's blood composition with respect to oxygen carrying capacity, oncotic pressure, hemostasis, and biochemistry. ${ }^{3}$ Recently, the concepts of damage control surgery and resuscitation have developed in an attempt to prevent or limit the development of the lethal triad of acidosis, hypothermia, and coagulopathy. ${ }^{18}$ Damage control surgery emphasizes early control of the bleeding by non-specific means, and damage control resuscitation aims to minimize hypothermia, acidosis, and coagulopathy. ${ }^{18}$

\section{Transfusion ratios and massive transfusion protocols}

The concept of hemostatic resuscitation is in concordance with damage control surgery and resuscitation. It aims to provide large quantities of not only blood but also plasma (and possibly other hemostatic products) to critically injured patients in an immediate and sustained fashion as part of a massive transfusion protocol. ${ }^{18}$ The rationale behind this approach is to maintain the normal content of whole blood, which contains RBCs, platelets, and plasma. While traditional transfusion strategies typically emphasized the use of RBC concentrates, with other components 


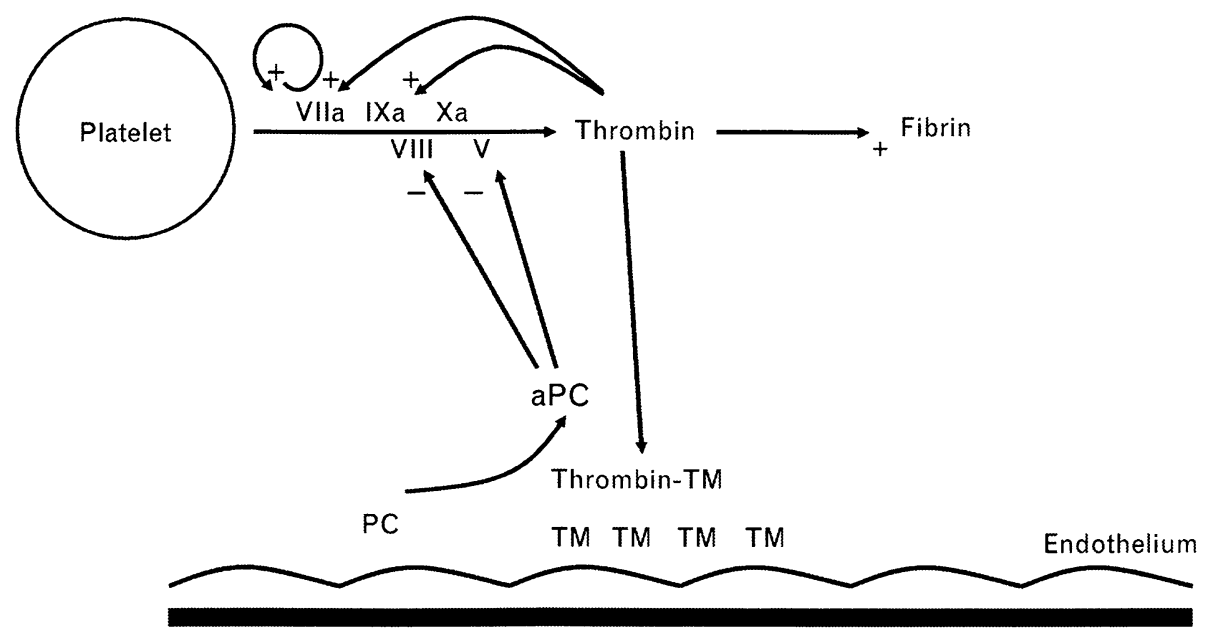

Fig. 1 Protein C-mediated anticoagulation. Thrombomodulin (TM) is expressed on the endothelium in the setting of trauma shock, diverting thrombin from fibrin formation. Instead, the thrombin-TM complex activates protein $\mathrm{C}$ (PC), which inhibits the activity of coagulation factors V and VIII. With permission from: Brohi $K$, Cohen MJ, Davenport RA. Acute coagulopathy of trauma: mechanism, identification and effect. Curr Opin Crit Care 2007; 13: $680-5$
Fig. 1 Anticoagulation médiée par la protéine C. La thrombomoduline (TM) est exprimée sur l'endothélium dans un contexte de choc traumatique, détournant la thrombine de la formation de fibrine. Le complexe thrombine-TM active plutôt la protéine $\mathrm{C}(\mathrm{PC})$, qui inhibe l'activité des facteurs de coagulation V et VIII. Avec l'aimable autorisation de: Brohi K, Cohen MJ, Davenport RA. Acute coagulopathy of trauma: mechanism, identification and effect. CurrOpinCrit Care 2007; 13: 680-5

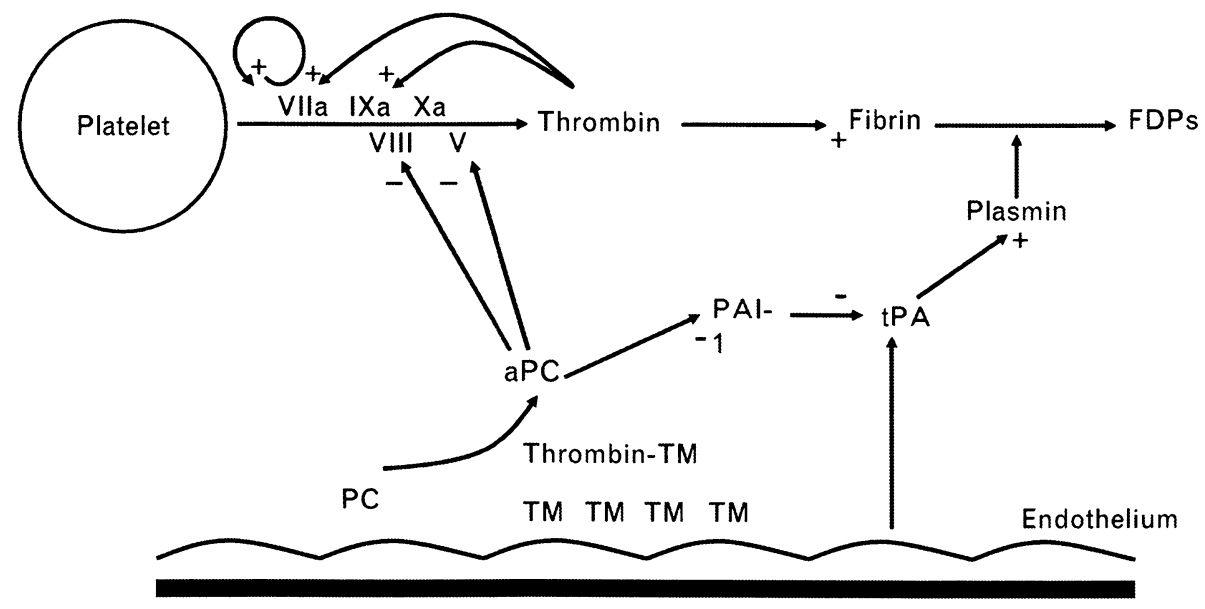

Fig. 2 Trauma-induced hyperfibrinolysis. Activated protein C (aPC) generated in the setting of trauma shock (see Fig. 1) also removes plasminogen activator inhibitor-1 (PAI-1). Reduction of this inhibitor results in increased fibrinolytic activity by means of increased function of tissue plasminogen activator (tPA). TM = thrombomodulin; FDP $=$ fibrin degradation products. With permission from: Brohi K, Cohen MJ, Davenport RA. Acute coagulopathy of trauma: mechanism, identification and effect. Curr Opin Crit Care 2007; 13: 680-5

reserved for demonstrable (laboratory) defects in coagulation, the concept of equitable, or nearly equitable, transfusion ratios has emerged with the aim of minimizing the impact and development of coagulopathy. ${ }^{18,19}$ Retrospective studies from combat hospitals and trauma centres have found an association between increased plasma-to$\mathrm{RBC}$ and platelet-to-RBC transfusion ratios and improved
Fig. 2 Fibrinolyse induite par le traumatisme. La protéine $C$ activée (PCa) générée dans le cadre d'un choc traumatique (voir la Fig. 1) élimine également l'inhibiteur-1 de l'activateur du plasminogène (PAI-1). Une baisse de cet inhibiteur entraîne une augmentation de l'activité fibrinolytique par le biais d'une augmentation de l'activité de l'activateur du plasminogène tissulaire (tPA). TM = thrombomoduline; $\mathrm{FDP}=$ produits de dégradation de la fibrine. Avec l'aimable autorisation de: Brohi K, Cohen MJ, Davenport RA. Acute coagulopathy of trauma: mechanism, identification and effect. CurrOpinCrit Care 2007; 13: 680-5

survival. ${ }^{18-24}$ Nevertheless, patients receiving high frozen plasma-RBC transfusion ratios were at higher risk of septic complications, an increased number of ventilator days, and increased length of stay in the intensive care unit. $^{25}$

Further, the Canadian National Advisory Committee on Blood and Blood Products has published a consensus developed at the Massive Transfusion Consensus 
Conference (June 2011, Toronto, Canada) that survivorship bias comprises a major obstacle in the proper interpretation of retrospective associations between transfusion ratios and trauma outcome, and limited scientific evidence currently exists to support ratio-driven (e.g., 1:1:1 ratios of $\mathrm{RBC}$, plasma, and platelet units) transfusion protocols. ${ }^{26}$ The effect of survivorship bias was shown compellingly by Snyder et al. who confirmed a survival benefit with highratio transfusion in their cohort of 134 patients, but only when the ratio was characterized at $24 \mathrm{hr}$ post-admission. ${ }^{27}$ Conversely, when the transfusion ratio was analyzed as a time-dependent covariate, the survival benefit was not shown. ${ }^{27}$ Since plasma transfusion tends to lag behind RBC transfusion in emergency situations, it has been suggested that patients survive because they endure long enough to receive high-ratio transfusion rather than because of highratio transfusion. Simmons et al. attempted to address survivor bias by reporting a 50\% improvement in survival among casualties wounded in Iraq compared with an earlier historical cohort. ${ }^{24}$ On the other hand, in the later cohort, the authors described several other elements of improved trauma care besides early treatment with high-ratio transfusion, including pre-hospital fluid bolus, tourniquet use, diligent temperature management, and improved access to advanced surgical capabilities. These other factors limit the ability to validate the independent contribution of hemostatic transfusion ratios. In another retrospective cohort, patients "lost" the survival benefit of high-ratio transfusion when the ratio was analyzed as a time-dependent covariate; however, de Biasi et al. did introduce the concept of "plasma deficit" with their observation that patients with greater deficits (i.e., the number of RBC units administered minus the number of plasma units) had increased mortality during the early phases (first three hours) of trauma care. ${ }^{28}$

As noted earlier, although high plasma-RBC transfusion ratios have been associated with survival benefit, they are not without risk of harm to patients; consequently, methods are needed to predict which patients might benefit most from such a protocol. Several scoring systems have been devised; however, the majority of these systems are cumbersome to use and require weighing variables in addition

Table 2 Assessment of blood consumption score

\begin{tabular}{lll}
\hline Dichotomous Variables & Yes $=1$ & No $=0$ \\
\hline Penetrating Mechanism & \\
Emergency Department SBP $<90 \mathrm{mmHg}$ & \\
Emergency Department $\mathrm{HR}>120$ beats $\cdot \mathrm{min}^{-1}$ & \\
Positive FAST & \\
Total & \\
\hline
\end{tabular}

$\mathrm{SBP}=$ systolic blood pressure, $\mathrm{HR}=$ heart rate, $\mathrm{FAST}=$ focused assessment with sonography for trauma to laboratory data. ${ }^{29}$ Cotton et al. devised a simplified nonweighted scoring system that uses the following four dichotomous variables that simply require a "yes" or "no" answer: a penetrating mechanism of injury; systolic blood pressure $<90 \mathrm{mmHg}$; heart rate $>120$ beats. $\mathrm{min}^{-1}$; and a positive focused assessment with sonography for trauma. ${ }^{29} \mathrm{~A}$ score of $\geq 2$ (two yes answers or more) was $75 \%$ sensitive and $85 \%$ specific in predicting the need for a high-ratio massive transfusion ${ }^{29}$ (Table 2).

While the available literature does not permit firm conclusions to be drawn regarding optimal transfusion ratios, it remains appropriate at the institutional level to devise protocol-based mechanisms for rapid blood delivery (i.e., massive transfusion protocols) that provide treating physicians with a reasonable and rapid initial ratio of blood products. This permits clinical focus to remain centred on patient management, which should emphasize surgical control of bleeding, maintenance of normothermia, minimization of electrolyte and acid-base disturbances, and the timely delivery of blood products that may be tailored to the clinical situation. ${ }^{7}$

Various centres have implemented transfusion protocols to help physicians manage the exsanguinating patient. ${ }^{17}$ Despite the lack of one common protocol for massive transfusion, all protocols have similar principles of almost equal transfusion ratios and damage control surgery. Cotton et al. devised a trauma exsanguination protocol that involved 10 RBC units, 4 frozen plasma units, and 2 platelet units. Patients in the trauma exsanguination protocol group had a lower overall 30 -day mortality rate. ${ }^{20}$ In a before and after study, Johansson et al. showed that hemostatic control resuscitation with blood products delivered as transfusion packages and transfusion guided by thromboelastography (TEG®) in accordance with a simple algorithm led to a reduction in 30-day mortality. ${ }^{22}$

\section{Point-of-care testing}

Despite enhanced understanding of the mechanisms underlying acute trauma coagulopathy, the clinical recognition of early coagulopathy remains problematic. Routine laboratory-based coagulation tests, such as prothrombin time/international normalized ratio (PT/INR) and activated partial thromboplastin time (aPTT) have several limitations in the acute clinical setting. Firstly, the delay from blood sampling to test result is usually $45 \mathrm{~min}$. Secondly, the coagulation tests are determined from plasma not whole blood. Thirdly, no information regarding platelet function is provided. Lastly, the time taken to clot formation provides no information regarding clot strength of subsequent fibrinolysis. $^{30}$ Taken together, these factors weaken the practicality and possibly the clinical relevance of PT/aPTT/ INR in the trauma setting. 
Recent investigations of point-of-care testing devices that assess the viscoelastic properties of whole blood, such as rotational thromboelastometry (ROTEM $\AA)^{31}$ and TEG have begun to underscore the inadequacies of traditional assays. Point-of-care testing allows blood to be analyzed at the bedside, which allows faster turnaround times. Furthermore, whole blood is used; this allows an in vivo assessment of the interactions of platelets with RBCs and provides useful information on platelet function. Moreover, the "blind" transfusion practices associated with trauma resuscitation have been shown to be insufficient. ${ }^{32}$ In a retrospective study, it was suggested that $82 \%$ of trauma patients requiring massive transfusions received insufficient amounts of fresh frozen plasma and platelets when managed by "blind" transfusion practices. ${ }^{32}$ Recently, it has been shown that hemostatic resuscitation guided by ROTEM and/or TEG was associated with improved survival benefit. ${ }^{22,33}$ Although, the evidence linking functional clotting assays with improved survival continues to develop, the European and British guidelines include ROTEM and/or TEG in their massive transfusion document. $^{34,35}$

\section{Pharmacologic agents}

Recombinant factor VIIa (rFVIIa) is an example of a nontraditional hemostatic agent that has been evaluated for massive transfusion - both in the trauma and non-trauma settings. To date, the use of this agent remains "off-label" other than for treating patients with acquired or congenital hemophilia with inhibitors. A recent Cochrane review of 4,290 patients (in both trauma and non-trauma settings) showed that there was no significant mortality benefit with the use of rFVIIa, even though it led to a modest reduction in blood loss and total RBCs transfused. ${ }^{36,37}$ Furthermore, there was a statistically non-significant trend toward an increase in thromboembolic phenomena with rFVIIa. $^{36,38}$ Hence, there is a lack of evidence for the use of rFVIIa in the setting of massive transfusion in patients without acquired or congenital hemophilia.

Tranexamic acid (TEA), a lysine analogue inhibitor of plasmin, has been shown to reduce transfusion requirements in a number of settings, including cardiovascular and orthopedic surgery. ${ }^{39}$ In 2010, the CRASH-2 investigators reported on the effect of administering a $1 \mathrm{~g}$ loading dose of TEA to trauma patients at the earliest possible opportunity, followed by $1 \mathrm{~g}$ delivered over eight hours. A statistically significant mortality reduction (risk ratio: 0.91) was observed among more than 20,000 trauma patients randomized to TEA vs placebo. ${ }^{40}$ While the study was not linked specifically to massive transfusion, eligible patients were those with trauma or those at risk for significant bleeding. Although the study was not designed to evaluate the mechanisms leading to mortality reduction, a hemostatic effect was implied because of risk reduction (risk ratio: 0.85 ) among the subgroup of patients dying specifically of hemorrhage. ${ }^{40}$ As noted earlier, fibrinolysis is increasingly recognized as a contributor to traumatic coagulopathy, and as such, a plausible mechanistic role for TEA is suggested. Meanwhile, the compelling observed mortality reduction, likely combined with the relatively low cost of this agent, has led to its inclusion in trauma management protocols at many centres in Canada (K. Pavenski, personal communication).

\section{Summary and conclusions}

Optimal management of the exsanguinating trauma patient remains a challenge for the clinician. The treatment of acute hemorrhage with damage control surgery and hemostatic resuscitation remains a priority. Concurrent recognition and management of the early and profound coagulopathy potentially associated with trauma victims may result in a reduction in mortality. Although the current literature does not permit firm conclusions to be drawn regarding optimal transfusion ratios, there is a shift towards the development of massive transfusion protocols that prevent the development of coagulopathy. Various massive transfusion protocols exist with the aim to provide physicians with a mechanism for rapid blood delivery and a reasonable ratio of blood products. Access to massive transfusion protocols may allow clinicians to focus on patient management with an emphasis on maintenance of normothermia and minimization of electrolyte and acidbase disturbances. Furthermore, there is promising evidence for the use of point-of-care testing, such as TEG and/ or ROTEM, to guide transfusion management. Early TEA administration has emerged as a useful pharmacologic adjunct to the management of trauma patients and may confer mortality benefit regardless of demonstrable coagulopathy or volume transfused.

\section{Clinical case scenario}

A 19-yr-old female pedestrian was brought to the emergency department (ED) after being struck by a sports utility vehicle driven at high speed. Her initial Glasgow coma scale was 5 at the scene of the accident. Her airway was secured in the ED, and the Advanced Trauma Life Support protocol was initiated. The trauma team assessment revealed multiple orthopedic fractures, a closed head injury, and a positive focused assessment with sonography for trauma. The massive transfusion protocol was initiated in the trauma bay. Initial blood work in the ED was as follows: $\mathrm{pH}$ 7.09; $\mathrm{pCO}_{2} 36 \mathrm{mmHg}$; $\mathrm{pO}_{2} 150 \mathrm{mmHg}$; $\mathrm{BE}$ (base excess) $-13.0 \mathrm{mmol} \cdot \mathrm{L}^{-1}$; international normalized 
ratio 1.95; activated partial thromboplastin time $44.5 \mathrm{sec}$; PT $18.7 \mathrm{sec}$; hemoglobin $55 \mathrm{~g} \cdot \mathrm{L}^{-1}$; platelets $99 \times 10^{9} \cdot \mathrm{L}^{-1}$; fibrinogen $0.77 \mathrm{~g} \cdot \mathrm{L}^{-1}$; and normal electrolytes. The patient is brought to the operating room for an emergent trauma laparotomy.

Instructions for completing the continuing professional development (CPD) module:

1. Read the current article and the references indicated in bold.

2. Go to: https://www.cpass2.umontreal.ca/selfassessment program/ and select the current module (Massive transfusion in the trauma patient)

3. Answer the multiple choice questions regarding the case scenario.

4. Once you have entered all of your answers, you will have access to experts' explanations for all the possible choices.

5. Participants may claim up to four hours of CPD, for a total of 12 credits under Section 3 of the CPD program of the Royal College of Physicians and Surgeons of Canada.

\section{Développement professionnel continu: Transfusions massives chez le patient traumatisé}

\begin{abstract}
Résumé
Objectif La transfusion massive a récemment reçu une définition dynamique, à savoir le remplacement de plus de quatre culots de globules rouges en l'espace d'une heure. L'objectif de ce module de développement professionnel continu est de revoir la physiopathologie du choc hémorragique chez le patient traumatisé et les stratégies actuelles de prise en charge d'un patient présentant une hémorragie massive.
\end{abstract}

Constatations principales Le patient présentant une hémorragie massive a besoin en même temps d'un contrôle de l'hémorragie et d'un traitement de remplacement du sang perdu. Bien que les transfusions massives soient associées à de nombreuses complications, tels que les troubles de l'équilibre acido-basique, les anomalies electrolytiques et l'hypothermie, l'elément peut-être le plus difficile à prendre en charge est la coagulopathie traumatique aiguë. Historiquement, la coagulopathie était attribuée à une dilution des facteurs de coagulation; toutefois, des données probantes accumulées récemment indiquent qu'il s'agit d'un processus multifactoriel associé à l'hypoperfusion, la consommation des facteurs de coagulation et l'hyperfibrinolyse. Dans le but de minimiser la coagulopathie traumatique aiguë, des protocoles de transfusions massives impliquant des proportions égales de culots de globules rouges, de plasma congelé et de plaquettes ont été proposés. Ce type de réanimation hémostatique avec des proportions presque égales de sang et de produits sanguins a amélioré la survie, mais n'est pas sans risque. En plus du rétablissement rapide et efficace $d u$ volume sanguin, le but spécifique de la prise en charge de la transfusion doit être de maintenir la capacité de transport d'oxygène, l'hémostase et la biochimie du patient.

Conclusion Les publications actuelles ne permettent pas de tirer des conclusions définitives concernant les proportions optimales à transfuser. Il reste toutefois approprié de concevoir un protocole de transfusion massive au niveau de l'établissement qui assure au départ aux médecins traitants la fourniture rapide d'une proportion raisonnable de produits. Cela permettrait une prise en charge centrée sur le patient en insistant sur le contrôle chirurgical de l'hémorragie, le maintien de la normothermie, le bilan électrolytique, l'équilibre acido-basique, et la livraison en temps opportun de produits sanguins.

Objectives Après avoir lu ce module, le lecteur devra être en mesure de:

1. Énumérer les complications associées aux transfusions massives dans un contexte de trauma;

2. Comprendre en quoi la coagulopathie présente chez le patient traumatisé diffère de celle observée dans le cadre de la chirurgie élective;

3. Identifier les modifications suggérées par les publications récentes pour la prise en charge de la transfusion massive dans un contexte de trauma;

4. Analyser les données probantes de la littérature pour la création de protocoles de transfusion massive.

\section{Article de synthèse}

Une hémorragie incontrôlée nécessitant une transfusion massive est le plus souvent observée au cours de la chirurgie traumatologique et reste une cause principale de décès. ${ }^{1-3}$ Chez les victimes de traumatismes, l'étendue des dommages tissulaires peut être imprévisible et l'intervalle écoulé entre l'hémorragie et le traitement peut être très variable. ${ }^{1}$ La coagulopathie est fréquente dans ce contexte en raison de l'hypothermie, de l'acidose, des lésions tissulaires, de l'hypoperfusion, de la dilution et de la consommation des facteurs de coagulation et des plaquettes. ${ }^{1,4}$ Le choc hémorragique est un état physiopathologique au cours duquel l'appareil circulatoire est incapable de répondre aux besoins en oxygène et de 
perfuser correctement les tissus. ${ }^{5}$ Les principes généraux de la prise en charge du choc hémorragique incluent le contrôle du saignement, le remplacement du volume circulant et la restauration de la capacité de transport de l'oxygène. Mais alors, il reste qu'il faut utiliser la transfusion avec parcimonie compte tenu des complications possibles associées aux transfusions de sang et de produits sanguins.

Une étude menée en Ontario a révélé que les patients traumatisés recevaient $13,4 \%$ de tous les produits sanguins transfusés et que $3 \%$ de ces victimes nécessitaient une transfusion massive. ${ }^{5}$ Approximativement $50 \%$ des patients traumatisés nécessitant une transfusion massive ont une coagulopathie; il est donc nécessaire de fournir aux cliniciens des directives pour la prise en charge de ces patients complexes. La transfusion massive a été définie de façon vague comme étant le remplacement d'un volume sanguin sur une période de 24 heures. ${ }^{6}$ Toutefois, une définition plus dynamique de la transfusion massive inclut la transfusion d'au moins quatre culots de globules rouges en l'espace d'une heure et un besoin continu de remplacement du sang dans un futur prévisible. ${ }^{6}$ La prise en charge d'un patient saignant massivement est complexe et vise en même temps au contrôle de l'hémorragie et au remplacement du volume de sang perdu. ${ }^{1}$ De plus, afin d'améliorer la survie, la prise en charge doit cibler la prévention des complications multifactorielles associées à la transfusion massive. Nous soulignons, dans cet article, les complications associées à la transfusion massive et les mécanismes de la coagulopathie induite par la transfusion. De façon plus spécifique, nous expliquons en quoi la coagulopathie induite par un traumatisme diffère de la coagulopathie rencontrée dans le cadre d'une chirurgie programmée. Enfin, nous présentons les récents progrès dans le domaine de la prise en charge de la transfusion massive, y compris les tests au chevet du patient, les proportions de produits transfusés et la mise en place de protocoles de transfusion massive.

\section{Complications liées aux transfusions massives}

Plusieurs complications aiguës et retardées de la transfusion massive sont bien connues, notamment: anomalies électrolytiques, acidose, hypothermie, infection, syndrome respiratoire aigu post-transfusionnel, surcharge circulatoire et coagulopathie. ${ }^{7}$

Anomalies électrolytiques et troubles de l'équilibre acido-basique (Tableau 1)

Diverses anomalies électrolytiques et troubles de l'équilibre acido-basique peuvent être retrouvés chez des patients nécessitant une transfusion massive. Parmi les victimes de blessures sans écrasement, une hyperkaliémie a été documentée chez38,5\% des patients transfusés comparativement à $2,8 \%$ des patients non transfusés. ${ }^{7} \mathrm{La}$ concentration de potassium dans les culots de globules rouges augmente avec la durée de conservation et peut atteindre $77 \mathrm{mEq} \cdot \mathrm{L}^{-1}{ }^{7}$ Les facteurs de risque de l'hyperkaliémie associée à la transfusion incluent le nombre absolu de culots de globules rouges transfusées, une insuffisance rénale sous-jacente, la vitesse de la transfusion sanguine et la gravité des lésions tissulaires. ${ }^{7}$ Une hypokaliémie peut aussi survenir après une transfusion; les facteurs qui interviennent semblent être :la pompe à ATPase de la membrane des globules rouges; la libération d'aldostérone, d'hormone antidiurétique et de catécholamines; et l'administration de citrate. Chaque culot de globules rouges contient $3 \mathrm{~g}$ de citrate, l'anticoagulant présent dans le sang de banque; $3 \mathrm{~g}$ de citrate correspondent à la quantité approximative que le foie d'un adulte en bonne santé peut métaboliser en cinq minutes. Par conséquent, une vitesse de transfusion supérieure à un culot de sang toutes les cinq minutes ou la présence d'une altération de la fonction hépatique peut entrainer une alcalose métabolique et une hypocalcémie secondaire à la toxicité du citrate. ${ }^{7}$ De même, une hypomagnésémie secondaire à la perfusion de liquides contenant peu de magnésium et la fixation du magnésium sur le citrate peuvent entrainer un allongement de l'intervalle QT au cours d'une transfusion massive.

Les patients nécessitant une transfusion massive peuvent également développer des troubles de l'équilibre acido-basique secondaires à l'hypoperfusion tissulaire et l'administration de sérum physiologique. ${ }^{4} \mathrm{La}$ survenue initiale d'une acidose métabolique peut être l'indicateur d'une mauvaise perfusion tissulaire, laquelle répond généralement aux mesures énergiques de réanimation. Il est important de noter que l'acidose aggrave la coagulopathie, car les plaquettes changent de forme à un $\mathrm{pH}<7,4$ et la formation de thrombine est inhibée à un $\mathrm{pH}<7,1 .{ }^{4}$ Enfin, l'acidose accélère la fibrinolyse, ce qui aggrave la coagulopathie. ${ }^{4}$

\section{Hypothermie (Tableau 1)}

Il a été démontré que l'anesthésie générale perturbait le contrôle normal de la thermorégulation. ${ }^{8}$ L'hypothermie pendant l'anesthésie générale suit un déroulement caractéristique. Il existe une importante diminution initiale de la température due à la redistribution, suivie d'une baisse plus lente secondaire à une perte de chaleur qui dépasse sa production par le métabolisme. ${ }^{8}$ Dans le contexte de chirurgie programmée, l'hypothermie peut habituellement être prévenue grâce à la perfusion de liquides réchauffés parce que d'entrée de jeu, la 
Tableau 1 Effets indésirables de l'hypothermie, de la toxicité au citrate et de l'hypercalcémie, par rapport à une transfusion massive et aux principes de prise en charge initiale

\begin{tabular}{|c|c|c|}
\hline & Effets indésirables & Principes de prise en charge \\
\hline \multirow[t]{5}{*}{ Hypothermie } & Diminution du métabolisme du citrate & Augmenter la température de la pièce \\
\hline & Diminution du métabolisme hépatique & $\begin{array}{l}\text { Réchauffer le patient en surface avec des lampes et } \\
\text { des couvertures chauffantes }\end{array}$ \\
\hline & Diminution de la clairance des médicaments & Perfuser de liquides réchauffés \\
\hline & Diminution de la synthèse des réactifs de la phase aiguë & Utiliser des gaz réchauffés et humidifiés \\
\hline & Diminution de la production des facteurs de coagulation & \\
\hline \multirow[t]{6}{*}{ Toxicité des citrates } & Tétanie & \multirow{6}{*}{$\begin{array}{l}\text { Surveiller et maintenir les concentrations de calcium } \\
\text { sérique }\end{array}$} \\
\hline & Allongement de l'intervalle QT & \\
\hline & Diminution de la contractilité myocardique & \\
\hline & Hypotension & \\
\hline & Élévation des pressions télédiastoliques & \\
\hline & Hypocalcémie & \\
\hline \multirow[t]{5}{*}{ Hypocalcémie } & Allongement de l'intervalle QT & \multirow{5}{*}{$\begin{array}{l}\text { Administrer du calcium intraveineux (par exemple, } \\
\text { le gluconate de calcium à } 10 \% \text { contient } 9 \mathrm{mg} \text { de } \\
\text { calcium élémentaire contre le chlorure de calcium } \\
\text { qui contient } 27 \mathrm{mg} \text { de calcium élémentaire) }\end{array}$} \\
\hline & Dépression myocardique & \\
\hline & Diminution des résistances vasculaires périphériques & \\
\hline & Tremblements & \\
\hline & Activité électrique sans pouls et fibrillation ventriculaire & \\
\hline Hypomagnésémie & Allongement de l'intervalle QT & Administrer du magnésium intraveineux \\
\hline \multirow[t]{6}{*}{ Acidose métabolique } & Coagulopathie & Effectuer une réanimation liquidienne énergique \\
\hline & Instabilité & \\
\hline & hémodynamique & \\
\hline & Dysfonctionnement rénal & Restaurer la perfusion tissulaire \\
\hline & & Surveiller l'excès de base \\
\hline & & Temporiser avec du $\mathrm{NaHCO}_{3}$ \\
\hline \multirow[t]{3}{*}{ Hyperkaliémie } & Ondes $\mathrm{T}$ pointues & Gluconate de calcium \\
\hline & & Dextrose $50 \%$ iv \\
\hline & Fibrillation ventriculaire & Insuline $10 \mathrm{U} i v$ \\
\hline \multirow[t]{2}{*}{ Hypokaliémie } & & Corriger l'alcalose métabolique \\
\hline & & $\begin{array}{l}\text { Limiter la perfusion de liquides contenant peu de } \\
\text { potassium }\end{array}$ \\
\hline \multirow[t]{4}{*}{ Coagulopathie } & Trouble de l'hémostase & Entreprendre une chirurgie de limitation des dégâts \\
\hline & & $\begin{array}{l}\text { Minimiser la perte de facteurs de coagulation et la } \\
\text { fibrinolyse }\end{array}$ \\
\hline & & Corriger l'acidose et l'hypocalcémie \\
\hline & & Maintenir la normothermie \\
\hline
\end{tabular}

température centrale du corps est normale. En revanche, le patient traumatisé présente un plus grand risque d'hypothermie pour plusieurs raisons et, notamment à cause de l'exposition, de la perfusion initiale de liquide non chauffé, de l'ouverture de cavités corporelles et d'une altération du contrôle de la thermorégulation. L'hypothermie a de nombreuses conséquences délétères, comme la baisse du métabolisme du citrate, la baisse de l'élimination des médicaments, une synthèse diminuée des réactifs de la phase aiguë et une diminution de production des facteurs de coagulation, tous des éléments qui aggravent la coagulopathie. ${ }^{7}$ De plus, l'hypothermie provoque une dysfonction réversible des plaquettes, altère significativement la cascade de la coagulation et favorise la fibrinolyse. ${ }^{1,4,7}$ À chaque $1{ }^{\circ} \mathrm{C}$ de baisse de la température corporelle correspond une réduction de $10 \%$ de l'activité des facteurs de coagulation. ${ }^{7}$ Il est important de rappeler que l'effet de cette hypothermie sur la cascade de la coagulation peut être sous-estimé car les tests de coagulation sont réalisés à $37{ }^{\circ} \mathrm{C}$. Les mesures à prendre pour prévenir l'hypothermie, à la fois au cours de la chirurgie programmée et dans un contexte de trauma, 
incluent la perfusion de liquides réchauffés, l'augmentation de la température de la pièce et le réchauffement du patient avec des couvertures à ventilation forcée.

\section{Syndrome respiratoire aigu post-transfusionnel}

Le syndrome respiratoire aigu post-transfusionnel(TRALI) est défini par la survenue brutale d'une hypoxémie avec infiltrats pulmonaires bilatéraux visibles sur les radiographies du thorax en l'absence de tout signe de surcharge circulatoire. La complication apparaît dans les six heures suivant une transfusion et ne peut être reliée à une autre cause de lésions pulmonaires aiguës, ni à un syndrome de détresse respiratoire aigue. ${ }^{7}$ Le TRALI est une cause majeure de morbidité et de mortalité en rapport avec la transfusion. ${ }^{9,10}$ Deux mécanismes distincts ont été proposés pour expliquer l'apparition d'un TRALI: le transfert passif des anticorps antileucocytaires provenant de donneurs ayant une allo-immunisation et le transfert de modificateurs de la réponse biologique accumulés au cours de la conservation des produits sanguins. ${ }^{9}$ Bien que la transfusion de produits sanguins soit un facteur de risque indépendant pour la survenue d'un TRALI, le risque de voir se développer une telle lésion dépend du type de produit sanguin. La transfusion de plasma est associée, par exemple, à un risque de 1:2000 de développer un TRALI, ce qui représente un risque supérieur à celui de la transfusion de globules rouges qui est de 1:5000. ${ }^{7,9}$ En faveur du mécanisme des anticorps anti leucocytaires, le sexe du donneur semble jouer un rôle contributif à l'apparition d'un TRALI. Les dons d'environ 10 à $20 \%$ de femmes ayant un antécédent de grossesse contiennent des anticorps anti leucocytaires. ${ }^{11}$ Les mesures pour réduire la survenue d'un TRALI, comme de fractionner de préférence le plasma donné par des femmes et d'ajouter du plasma de donneurs masculins aux concentrés plaquettaires ont actuellement cours en au Canada, au Royaume-Uni et aux États-Unis.

\section{Coagulopathie induite par le traumatisme}

La coagulopathie associée à une transfusion massive est un processus multifactoriel et multicellulaire. ${ }^{6}$ Sans aucun doute, il y a une dilution des facteurs de coagulation quand une coagulopathie est associée à une transfusion massive ${ }^{12}$; toutefois, ce processus n'est pas de par nature uniquement une affaire de dilution; la consommation des facteurs de coagulation ainsi que l'hyper fibrinolyse jouent également un rôle significatif. ${ }^{7,13}$ Les modèles traditionnels qui expliquent les troubles de coagulation comme s'ils étaient acquis expressément du fait du traumatisme externe et des mesures énergiques de réanimation (comme l'hémodilution, hypothermie, l'acidose et la perte de facteurs de coagulation) sont insuffisants. ${ }^{14}$ En effet, un sous-groupe de patients souffrant de traumatisme aigu manifeste une coagulopathie très précoce dont le mécanisme paraît tout à fait distinct des concepts traditionnels des troubles acquis de la coagulation. Même si la coagulopathie associée à un traumatisme porte plusieurs noms (par exemple: coagulopathie traumatique aiguë, coagulopathie précoce induite par un traumatisme, coagulopathie aiguë endogène et coagulopathie aiguë du choc traumatique), nous y ferons référence sous le terme de coagulopathie traumatique aiguë dans le reste de cette étude. Le trouble de coagulation observable dans la coagulopathie traumatique aiguë apparait tôt et est de plus en plus identifié comme résultant de l'activation des cascades de protéases endogènes en présence un état de choc. Ces cascades créent un état d'hypercoagulabilité qui agit indépendamment des effets prévisibles de la diminution de facteurs de coagulation, de la dilution et de la dysfonction des protéases secondaires à l'acidose et à l'hypothermie.

En reconnaissant qu'il est peu probable que la coagulopathie traumatique aiguë relève d'un seul mécanisme sous-jacent, Broni et coll. ${ }^{15}$ ont élaboré une explication plausible de la coagulopathie qui survient dans environ $25 \%$ des cas. ${ }^{16}$ Cette coagulopathie n'est pas attribuable au développement de l'acidose, à la diminution en facteurs de coagulation ou à l'hypothermie. L'observation selon laquelle la coagulopathie se développe rarement sans les effets incitatifs d'un choc et d'une hypoperfusion tissulaire est au centre de ce mécanisme. ${ }^{15}$ L'hypoperfusion tissulaire aboutit à une expression endothéliale de la thrombomoduline qui forme complexe avec la thrombine générée de manière normale par la blessure initiale; l'agrégat résultant active la protéine $\mathrm{C}$ pour former la protéine $\mathrm{C}$ activée. De cette façon, on identifie deux mécanismes distincts d'hypocoagulabilité: tout d'abord, la protéine $\mathrm{C}$ activée inactive le facteur Va et le facteur VIIIa; ensuite, la thrombine est détournée de son rôle naturel dans la formation de la fibrine car elle forme plutôt des complexes avec la thrombomoduline (Figs. 1 et 2).

De plus, la formation de protéine $C$ activée induite par le choc entraîne une consommation de l'inhibiteur de l'activateur du plasminogène. Ce dernier sert normalement à réguler l'activateur du plasminogène tissulaire (tPA) en freinant son rôle (par le biais de la formation de plasmine issue $\mathrm{du}$ plasminogène) dans la promotion de la dégradation du caillot de fibrine. La protéine $\mathrm{C}$ activée sert ainsi à laisser libre cours à la tendance de l'endothélium traumatisé à déclencher la fibrinolyse (par le biais d'une expression de la tPA); en conséquence, la fibrinolyse est également comprise comme étant une composante importante du mécanisme global de la coagulopathie traumatique. 


\section{Prise en charge de la transfusion massive dans un contexte de trauma}

La prise en charge du patient traumatisé en hémorragie comprend le contrôle de l'hémorragie et le remplacement simultané du volume sanguin perdu. Historiquement, le patient qui saigne était pris en charge principalement au moyen de solutions cristalloïdes isotoniques et de culots de globules rouges dépourvus de plasma. Dans une grande étude rétrospective, les patients traumatisés nécessitant une transfusion $>50$ culots de globules rouges au cours des 24 premières heures d'hospitalisation avaient un taux de mortalité de $57 \%{ }^{17}$ Même dans ces conditions, cette méthode traditionnelle de prise en charge ne parvient pas à régler le problème de $25 \%$ des victimes de traumatismes qui développent une coagulopathie précoce et intense, susceptible de s'aggraver avec la transfusion de globules rouges par une coagulopathie de dilution. ${ }^{18}$ Donc, en plus d'une restauration rapide et efficace du volume sanguin, le but spécifique de la prise en charge de la transfusion doit être de maintenir la composition du sang du patient en termes de capacité de transport d'oxygène, de pression oncotique, d'hémostase et de biochimie. ${ }^{3}$ Récemment, les concepts de réanimation et de chirurgie de limitation des dégâts se sont développés dans un but de prévention ou de limitation de l'apparition de la triade mortelle: acidose, hypothermie et coagulopathie. ${ }^{18}$ Dans le contexte de limitation des dégâts, la chirurgie a pour objectif le contrôle précoce du saignement par des moyens non spécifiques et la réanimation vise à minimiser l'hypothermie, l'acidose et la coagulopathie. ${ }^{18}$

\section{Ratios transfusionnels et protocoles de transfusion massive}

Le concept de réanimation hémostatique est cohérent avec la chirurgie et la réanimation de limitation des dégâts. Il vise à fournir de grandes quantités non seulement de sang, mais aussi de plasma (et éventuellement d'autres produits hémostatiques) à des patients très gravement blessés, de façon immédiate et soutenue, dans le cadre d'un protocole de transfusion massive. ${ }^{18}$ Le justificatif de cette approche est le maintien du contenu normal en sang entier (constitué de globules rouges, de plaquettes et de plasma). Alors que les stratégies traditionnelles de transfusion insistent sur l'utilisation de culots de globules rouges, en reléguant les autres composants à l'apparition de troubles démontrables (en laboratoire) de la coagulation, le concept de ratios de transfusions équitables (ou presque équitables) a fait son apparition dans le but de minimiser l'impact et l'évolution de la coagulopathie. ${ }^{18,19}$ Des études rétrospectives menées dans des hôpitaux militaires en zone de combat et des centres de traumatologie ont montré une association entre l'augmentation des ratios plasma/globules rouges et l'amélioration de la survie. ${ }^{18-24}$ Néanmoins, des patients recevant des ratios transfusionnels élevés de plasma congelé/globules rouges ont eu un risque plus élevé de complications infectieuses, un plus grand nombre de jours sous ventilateur et un séjour prolongé aux soins intensifs. ${ }^{25}$

En outre, le Comité national consultatif canadien sur le sang et les produits sanguins a publié un consensus élaboré au cours de la Conférence de consensus sur la transfusion massive qui s'est tenue à Toronto en juin 2011: le biais de survie constitue un obstacle majeur pour une interprétation correcte des associations faites rétrospectivement entre les ratios transfusionnels et le pronostic du traumatisme; par ailleurs, nous ne disposons actuellement que de données scientifiques limitées à l'appui de protocoles transfusionnels reposant sur des ratios (par exemple, un ratio d'unités de globules rouges/plasma/plaquettes de 1:1:1). ${ }^{26}$ L'effet du biais de survie a été montré de façon irréfutable par Snyder et coll., qui ont confirmé un avantage en termes de survie avec des transfusions à ratio élevé dans leur cohorte de 134 patients, mais seulement lorsque ce ratio était établi 24 heures après l'admission. ${ }^{27}$ Inversement, lorsque le ratio transfusionnel était analysé comme covariable temps-dépendante, l'avantage sur la survie n'a pas été retrouvé. ${ }^{27}$ Dans la mesure où les transfusions de plasma tendent à être retardées par rapport aux transfusions de globules rouges dans les situations d'urgence, il a été suggéré que les patients survivent parce qu'ils résistent assez longtemps pour recevoir une transfusion à ratio élevé plutôt que parce qu'ils reçoivent une transfusion à ratio élevé. Simmons et coll. ont tenté d'aborder le biais de survie en décrivant une amélioration de $50 \%$ de la survie chez les blessés en Irak, comparativement à une cohorte historique antérieure. ${ }^{24} \mathrm{D}$ 'un autre côté, dans cette cohorte, les auteurs ont décrit plusieurs autres éléments d'amélioration des soins en traumatologie outre le traitement précoce par une transfusion à ratio élevé, comme l'administration de boulus de liquides avant l'hospitalisation, la pose de garrots, une gestion diligente de la température et un accès amélioré à des ressources chirurgicales avancées. Ces autres facteurs limitent la possibilité de valider la contribution indépendante des ratios de transfusion hémostatique. Dans une autre cohorte rétrospective, les patients « ont perdu » le bénéfice pour la survie que conférait la transfusion à ratio élevé quand ce ratio a été analysé sous forme de covariable temps-dépendante. Cependant, de Biasi et coll. ont introduit le concept de « déficit plasmatique » avec leur observation selon laquelle les patients ayant des déficits plus importants (c'est-à-dire le nombre de culots de globules rouges administrées moins le nombre d'unités de plasma) avaient une mortalité accrue au cours des phases précoces (les trois premières heures) des soins de traumatologie. ${ }^{28}$ 
Tableau 2 Évaluation du score de consommation sanguine

\begin{tabular}{lll}
\hline Variables dichotomiques & Oui $=1$ & Non $=0$ \\
\hline Mécanisme pénétrant & & \\
TAS au service des urgences $<90 \mathrm{mmHg}$ & \\
FC au service des urgences $>120 \mathrm{bat} \cdot \mathrm{min}^{-1}$ & \\
FAST positif & \\
Total &
\end{tabular}

TAS = Pression artérielle systolique, $\mathrm{FC}=$ Fréquence cardiaque, FAST = Evaluation échographique ciblée pour traumatisme

Comme cela a été dit plus haut, même si les ratios élevés de transfusion plasma/globules rouges ont été associés à un bénéfice pour la survie, ils ne sont pas dénués de risques pour les patients; par conséquent, des méthodes sont nécessaires pour prédire quels patients pourraient bénéficier le plus d'un tel protocole. Quelques systèmes de notation ont été proposés, mais la majorité de ces systèmes sont lourds à utiliser et nécessitent des variables de pondération en plus de données de laboratoire. ${ }^{29}$ Coton $e t$ coll. ont conçu un système de notation simplifié et non pondéré qui utilise quatre variables dichotomiques nécessitant simplement une réponse par «oui » ou « non »: un mécanisme lésionnel pénétrant; tension artérielle systolique $<90 \mathrm{mmHg}$; fréquence cardiaque $>$ $120 \mathrm{bat} \mathrm{min}^{-1}$; et une évaluation échographique ciblée pour traumatisme (FAST) ${ }^{29} \mathrm{Un}$ score $\geq 2$ (deux réponses « oui » ou plus) avait une sensibilité de $75 \%$ et une spécificité de $85 \%$ pour prédire la nécessité d'une transfusion massive à ratio élevé en $^{29}$ (Tableau 2).

Bien que la littérature disponible ne permette pas de tirer des conclusions définitives concernant les ratios optimaux de transfusion, la mise en place de mécanismes basés sur un protocole reste appropriée au niveau de l'établissement pour la livraison rapide du sang (c'est-à-dire des protocoles de transfusion massive) qui apportent rapidement au médecin traitant un ratio initial raisonnable de produits sanguins. Cela permet d'assurer une prise en charge du patient centrée sur la clinique, en insistant sur le contrôle chirurgical du saignement, le maintien de la normothermie, la minimisation des désordres électrolytiques et acido-basiques, en plus de l'administration en temps opportun de produits sanguins qui seront adaptés à la situation clinique. ${ }^{7}$

Différents centres ont mis en œuvre des protocoles transfusionnels pour aider les médecins à prendre en charge des patients vidés de leur sang. ${ }^{17}$ Malgré l'absence de protocole commun pour les transfusions massives, tous les protocoles reposent sur les mêmes principes de ratios de transfusion à peu près égaux et de chirurgie de limitation des dégâts. Coton et coll. ont rédigé un protocole d'exsanguination traumatologique faisant appel à 10 culots de globules rouges, 4 unités de plasma congelé et 2 unités de plaquettes. Les patients ayant bénéficié du protocole d'exsanguination traumatologique ont eu un taux de mortalité globale inférieur à 30 jours. ${ }^{20}$ Dans une étude avant-après, Johansson et coll. ont montré que la réanimation avec contrôle hémostatique au moyen de produits sanguins administrés sous forme de trousse de transfusion et de transfusion guidée par thromboélastographie (TEG®) selon un algorithme simple, entraînait une réduction de la mortalité à 30 jours. $^{22}$

Tests au chevet des patients

Malgré une meilleure connaissance des mécanismes sous-jacents de la coagulopathie traumatique aiguë, son identification précoce en clinique reste problématique. Les tests de coagulation basée sur les analyses standard de laboratoire, tels que le temps de prothrombine/le rapport international normalisé (PT/INR) et le temps de thromboplastine partielle activée (aPTT) ont de nombreuses limites dans un contexte clinique aigu. Tout d'abord, le délai écoulé entre le prélèvement de sang et le résultat $\mathrm{du}$ test est d'habituellement 45 minutes. Deuxièmement, les tests de coagulation sont déterminés à partir du plasma et non du sang entier. Troisièmement, aucune information concernant la fonction plaquettaire n'est fournie. Enfin, le temps de formation du caillot n'apporte aucune information sur la résistance du caillot à la fibrinolyse ultérieure. ${ }^{30}$ Pris ensemble, ces facteurs affaiblissent l'aspect pratique et, peut-être, la pertinence clinique du PT/aPTT/INR dans un contexte de traumatologie.

Des études récentes portant sur les dispositifs de tests évaluant les propriétés viscoélastiques du sang total au chevet du patient, comme la thromboélastométrie rotative $\left(\text { ROTEM }{ }^{\circledR}\right)^{31}$ et le TEG ont commencé à souligner les insuffisances des tests traditionnels. Les tests au chevet du patient permettent d'analyser le sang à proximité immédiate du patient et d'avoir l'information plus rapidement. En outre, ils utilisent du sang entier; cela permet une évaluation in vivo de l'interaction des plaquettes avec les globules rouges et procure une information utile sur la fonction plaquettaire. De plus, les pratiques transfusionnelles «aveugles » en réanimation traumatologique ont montré qu'elles étaient insuffisantes. ${ }^{32}$ Une étude rétrospective a suggéré que $82 \%$ des patients de traumatologie nécessitant des transfusions massives avaient reçu des quantités insuffisantes de plasma congelé frais et de plaquettes quand ils étaient pris en charge selon des pratiques transfusionnelles « aveugles ». ${ }^{32}$ Il a été récemment montré que la réanimation hémostatique guidée par ROTEM et/ou TEG était associée à une amélioration de la survie. ${ }^{22,33}$ Bien que les données probantes associant les tests fonctionnels de 
coagulation à l'amélioration de la survie continuent à apparaître, les directives européennes et britanniques incluent le ROTEM et/ou le TEG dans leurs documents sur la transfusion massive. ${ }^{34,35}$

\section{Agents pharmacologiques}

Le facteur recombinant VIIa (rFVIIa) est un modèle d'agent hémostatique non traditionnel qui a été évalué pour les transfusions massives, à la fois dans cadre traumatologique et dans un cadre non traumatologique. À ce jour, l'utilisation de cet agent reste « hors indication », sauf pour les patients ayant une hémophilie acquise ou congénitale avec présence d'inhibiteurs. Une analyse Cochrane récente ayant porté sur 4290 patients (à la fois dans un contexte traumatologique et non traumatologique) a montré que l'utilisation du rFVIIa n'entraînait pas de bénéfices significatifs sur la mortalité, même s'il entraînait une réduction modeste des pertes sanguines et de la quantité totale de globules rouges transfusés. ${ }^{36,37}$ En outre, l'utilisation du rFVIIa était associée à une tendance statistiquement non significative vers une augmentation du phénomène thromboembolique. ${ }^{36,38} \mathrm{En}$ conséquence, il n'existe pas de données probantes en faveur de l'utilisation du rFVIIa dans un contexte de transfusion massive chez des patients sans hémophilie, acquise ou congénitale.

Il a été montré que l'acide tranexamique (TEA), un analogue de la lysine inhibiteur de la plasmine, réduisait le besoin de transfusion dans un certain nombre de situations, y compris en chirurgie cardiovasculaire et orthopédique. ${ }^{39} \mathrm{En} 2010$, les investigateurs de l'étude CRASH-2 ont décrit les effets de l'administration, aussitôt que possible, d'une dose de charge de $1 \mathrm{~g}$ de TEA à des patients traumatisés, suivie d'une perfusion de $1 \mathrm{~g}$ sur huit heures. Une réduction statistiquement significative de la mortalité (rapport de risque: 0,91) a été observée parmi plus de 20000 patients traumatisés randomisés dans le groupe TEA par rapport au placebo. ${ }^{40}$ Bien que cette étude n'ait pas été directement en rapport avec la transfusion massive, les patients admissibles étaient des traumatisés ou des patients présentant un risque d'hémorragie significatif. L'étude n'était pas non plus conçue pour évaluer les mécanismes menant à une réduction de la mortalité, mais un effet hémostatique était néanmoins impliqué en raison de la réduction du risque (rapport de risque: 0,85) dans le sous-groupe de patients spécifiquement décédés d'hémorragie. ${ }^{40}$ Comme indiqué plus haut, le rôle de la fibrinolyse comme élément contributif de la coagulopathie traumatique est de plus en plus admis et, en tant que tel, un rôle plausible du TEA dans ce mécanisme est suggéré. Pendant ce temps, la réduction convaincante de la mortalité observée, probablement combinée avec le coût relativement faible de cet agent, a conduit à son inclusion dans les protocoles de prise en charge des traumatismes dans de nombreux centres canadiens (K. Pavenski, communication personnelle).

\section{Résumé et conclusions}

La prise en charge optimale d'un patient traumatisé avec exsanguination reste un défi pour le clinicien. Le traitement de l'hémorragie aiguë avec chirurgie de limitation des dégâts et réanimation hémostatique reste une priorité. L'identification et la prise en charge simultanée de la coagulopathie précoce et intense que peuvent arborer les victimes de traumatismes peuvent aboutir à une baisse de la mortalité. Bien que les publications actuelles ne permettent pas de tirer des conclusions définitives sur les ratios optimaux de transfusion, la tendance se dessine en faveur de l'élaboration de protocoles de transfusion massive prévenant le développement d'une coagulopathie. Il existe différents protocoles de transfusion massive dont l'objectif est de fournir aux médecins un mécanisme de livraison rapide de sang et un ratio raisonnable de produits sanguins. L'accès à des protocoles de transfusion massive peut permettre aux cliniciens de se concentrer sur la prise en charge du patient en insistant sur le maintien de la normothermie et la minimisation des désordres électrolytiques et acido-basiques. En outre, il existe des données probantes prometteuses concernant l'utilisation des tests au chevet des patients, tels que le TEG et/ou le ROTEM, pour guider la prise en charge de la transfusion. Une administration précoce de TEA s'est avérée un ajout pharmacologique utile pour la prise en charge des patients traumatisés et elle peut apporter un bénéfice sur la mortalité, indépendamment de l'existence d'une coagulopathie démontrable ou du volume transfusé.

\section{Scénario de cas clinique}

Une jeune femme de 19 ans, piétonne, a été amenée au service des urgences après avoir été frappée par un véhicule utilitaire sport roulant à grande vitesse. Son score de Glasgow initial était de 5 sur la scène de l'accident. Ses voies aériennes ont été sécurisées au service des urgences et un protocole de soins avancés en réanimation traumatologique a été entrepris. L'évaluation de l'équipe de traumatologie a relevé de multiples factures, un traumatisme crânien fermé, et une évaluation orientée positive avec échographie pour traumatisme. Un protocole de transfusion massive a commencé en salle de traumatologie. Les résultats des tests sanguins initiaux pratiqués au service des urgences étaient les suivants: pH 7,09; $\quad \mathrm{pCO}_{2} 36 \mathrm{mmHg} ; \quad \mathrm{pO}_{2} 150 \mathrm{mmHg} ; \quad \mathrm{EB}$ 
(excès de base) $-13,0 \mathrm{mmol} \cdot \mathrm{L}^{-1}$; rapport normalisé international (INR) 1,95; temps de thromboplastine partielle activée $44,5 \mathrm{~s}$; TP $18,7 \mathrm{~s}$; hémoglobine $55 \mathrm{~g} \cdot \mathrm{L}^{-1}$; plaquettes $99 \times 10^{9} \cdot \mathrm{L}^{-1}$; fibrinogène $0,77 \mathrm{~g} \cdot \mathrm{L}^{-1}$; et électrolytes normaux. La patiente est conduite en salle d'opération pour laparotomie exploratoire urgente.

Directives pour compléter le module de développement professionnel continu (DPC)

1. Lisez cet article et les références en gras.

2. Allez à: https://www.cpass2.umontreal.ca/selfassessment program/ et sélectionnez le module actuel (Transfusions massives chez le patient traumatisé).

3. Répondez aux questions à choix de réponses concernant le cas clinique.

4. Une fois que vous avez saisi toutes vos réponses, vous aurez accès aux explications d'experts pour tous les choix possibles.

5. Les participants peuvent réclamer un maximum de quatre heures de DPC pour un total de 12 crédits sous la Section 3 du programme de DPC du Collège royal des médecins et chirurgiens du Canada.

Funding support The Department of Anesthesia, St. Michael's Hospital.

Conflicts of interest None declared.

\section{References}

1. Hardy JF, de Moerloose P, Samama CM. The coagulopathy of massive transfusion. Vox Sang 2005; 89: 123-7.

2. Callcut RA, Johannigman JA, Kadon KS, Hanseman DJ, Robinson BR. All massive transfusion criteria are not created equal: defining the predictive value of individual transfusion triggers to better determine who benefits from blood. J Trauma 2011; 70: 794-801.

3. Sihler KC, Napolitano LM. Massive transfusion. Chest 2009; 136: 1654-67.

4. Johansson PI, Ostrowski SR, Secher NH. Management of major blood loss: an update. Acta Anaesthesiol Scand 2010; 54: 1039-49.

5. Tien H, Nasciemento B Jr, Callum J, Rizoli S. An approach to transfusion and hemorrhage in trauma: current perspectives on restrictive transfusion strategies. Can J Surg 2007; 50: 202-9.

6. Hardy JF, de Moerloose P, Samama CM. Massive transfusion and coagulopathy: pathophysiology and implications for clinical management. Can J Anesth 2006; 53 (Suppl 2): S4057

7. Sihler KC, Napolitano LM. Complications of massive transfusion. Chest 2010; 137: 209-20.

8. Sessler DI. Mild perioperative hypothermia. N Engl J Med 1997; 336: 1730-7.

9. Khan H, Belsher J, Yilmaz M, et al. Fresh-frozen plasma and platelet transfusions are associated with development of acute lung injury in critically ill medical patients. Chest 2007; 131: 1308-14.
10. Cohen H, Watt A, Jones H, et al. Serious Hazards of Transfusion: Annual Report 2010 Summary. Available from URL: http://www.shotuk.org/wp-content/uploads/2011/07/SHOT-2010Summary1.pdf (accessed May 2012).

11. Eder AF, Benjamin RJ. TRALI risk reduction: donor and component management strategies. J Clin Apher 2009; 24: 122-9.

12. Miller RD, Robbins TO, Tong MJ, Barton SL. Coagulation defects associated with massive blood transfusions. Ann Surg 1971; 174: 794-801.

13. Reed RL 2nd, Ciaverella D, Heibach DM, et al. Prophylactic platelet administration during massive transfusion. A prospective, randomized, double-blind clinical study. Ann Surg 1986; 203: 40-8.

14. Cohen MJ, West M. Acute traumatic coagulopathy: from endogenous acute coagulopathy to systemic acquired coagulopathy and back. J Trauma 2011; 70: S47-9.

15. Brohi K, Cohen MJ, Davenport RA. Acute coagulopathy of trauma: mechanism, identification and effect. Curr Opin Crit Care 2007; 13: 680-5.

16. Brohi K, Singh J, Heron M, Coats T. Acute traumatic coagulopathy. J Trauma 2003; 54: 1127-30.

17. Malone DL, Hess JR, Fingerhut A. Massive transfusion practices around the globe and a suggestion for a common massive transfusion protocol. J Trauma 2006; 60(6 Suppl): S91-6.

18. Johansson PI, Stensballe J. Hemostatic resuscitation for massive bleeding: the paradigm of plasma and platelets-a review of the current literature. Transfusion 2010; 50: 701-10.

19. Borgman MA, Spinella PC, Perkins JC, et al. The ratio of blood products transfused affects mortality in patients receiving massive transfusions at a combat support hospital. J Trauma 2007; 63: 805-13.

20. Cotton BA, Gunter OI, Isbell J, et al. Damage control hematology: the impact of a trauma exsanguination protocol on survival and blood product utilization. J Trauma 2008; 64: 1177-83.

21. Gunter OL, Au KB, Isbell JM, Mowery NT, Young PP, Cotton BA. Optimizing outcomes in damage control resuscitation: identifying blood product ratios associated with improved survival. J Trauma 2008; 65: 527-34.

22. Johansson PI, Stensballe J., Effect of haemostatic control resuscitation on mortality in massively bleeding patients: a before and after study. Vox Sang 2009; 96: 111-8.

23. Holcomb JB, Jenkins D, Rhee P, et al. Damage control resuscitation: directly addressing the early coagulopathy of trauma. J Trauma 2007; 62: 307-10.

24. Simmons $J W$, White $C E$, Eastridge BJ, et al. Impact of improved combat casualty care on combat wounded undergoing exploratory laparotomy and massive transfusion. J Trauma 2011; 71: S82-6.

25. Maegele $M$, Lefering $R$, Paffrath $T$, et al. Red blood cell to plasma ratios transfused during massive transfusion are associated with mortality in severe multiply injury: a retrospective analysis from the Trauma Registry of the Deutsche Gesellschaft für Unfallchirurgie. Vox Sang 2008; 95: 112-9.

26. Dzik WH, Blajchman MA, Fergusson D, et al., Clinical review: Canadian National Advisory Committee on Blood and Blood Products - Massive transfusion consensus conference 2011: report of the panel. Crit Care 2011; 15: 242.

27. Snyder CW, Weinberg JA, McGwin G Jr, et al. The relationship of blood product ratio to mortality: survival benefit or survival bias? J Trauma 2009; 66: 358-64.

28. de Biasi AR, Stansbury LG, Dutton RP, Stein DM, Scalea TM, Hess $J R$. Blood product use in trauma resuscitation: plasma deficit versus plasma ratio as predictors of mortality in trauma (CME). Transfusion 2011; 51: 1925-32.

29. Cotton BA, Dossett LA, Haut ER, et al. Multicenter validation of a simplified score to predict massive transfusion in trauma. J Trauma 2010; 69(Suppl 1): S33-9. 
30. Ganter MT, Hofer CK. Coagulation monitoring: current techniques and clinical use of viscoelastic point-of-care coagulation devices. Anesth Analg 2008; 106: 1366-75.

31. Davenport R, Manson J, De'Ath A, et al. Functional definition and characterization of acute traumatic coagulopathy. Crit Care Med 2011; 39: 2652-8.

32. Geeraedts LM Jr, Demiral H, Schapp NP, Kamphuisen $P W$, Pompe JC, Frolke JP. 'Blind' transfusion of blood products in exsanguinating trauma patients. Resuscitation 2007; 73 : 382-8.

33. Schochl H, Nienaber U, Hofer G, et al. Goal-directed coagulation management of major trauma patients using thromboelastometry $\left(\right.$ ROTEM $\left.{ }^{\circledR}\right)$-guided administration of fibrinogen concentrate and prothrombin complex concentrate. Crit Care 2010; 14: R55.

34. Rossaint R, Bouillon B, Cerny V, et al. Management of bleeding following major trauma: an updated European guideline. Crit Care 2010; 14: R52.

35. British Committee for Standards in Haematology; Stainsby D, MacLennan S, Thomas D, Isaac J, Hamilton PJ. Guidelines on the management of massive blood loss. Br J Haematol 2006; 135: 634-41.
36. Simpson E, Lin Y, Stanworth S, Birchall J, Doree C, Hyde C. Recombinant factor VIIa for the prevention and treatment of bleeding in patients without haemophilia. Cochrane Database Syst Rev 2012; 3: CD005011.

37. Boffard KD, Riou B, Warren B, et al. Recombinant factor VIIa as adjunctive therapy for bleeding control in severely injured trauma patients: two parallel randomized, placebo-controlled, doubleblind clinical trials. J Trauma 2005; 59: 8-15.

38. Levi M, Levi JH, Andersen HF, Truloff D. Safety of recombinant activated factor VII in randomized clinical trials. N Engl J Med 2010; 363: 1791-800.

39. Henry DA, Carless PA, Moxey AJ, et al. Anti-fibrinolytic use for minimising perioperative allogeneic blood transfusion (Review).The Cochrane Collaboration 2009. Available from URL: http://www.update-software.com/bcp/wileypdf/en/cd001886.pdf (accessed August 2012).

40. Williams-Johnson JA, McDonald AH, Strachan GG, Williams $E W$. Effects of tranexamic acid on death, vascular occlusive events, and blood transfusion in trauma patients with significant haemorrhage (CRASH-2): a randomised, placebo-controlled trial. West Indian Med J 2010; 59: 612-24. 